\title{
Examining the trade-offs of palm oil production and consumption from a sustainable diets perspective: lessons learned from Myanmar
}

\author{
Shauna M Downs ${ }^{1, *}$, Khristopher Nicholas ${ }^{2}$, Kay Khine Linn $^{3}$ and Jessica Fanzo 4 \\ 'Department of Urban-Global Public Health, Rutgers School of Public Health, One Riverfront Plaza, Suite 1020, \\ Newark, NJ 07 102, USA: ${ }^{2}$ Carolina Population Center, University of North Carolina at Chapel Hill, Chapel Hill, NC, \\ USA: ${ }^{3}$ HelpAge International, Yangon, Myanmar: ${ }^{4}$ Berman Institute of Bioethics, Nitze School of Advanced \\ International Studies, and Bloomberg School of Public Health, Johns Hopkins University, Washington, DC, USA
}

Submitted 28 April 2021: Final revision received 20 September 2021: Accepted 18 0ctober 2021: First published online 15 November 2021

\begin{abstract}
Objective: The aim of this study was to examine the trade-offs related to the production and consumption of palm oil in Myanmar from a sustainable diets perspective.

Design: We used an enhanced value chain analysis approach that included semistructured interviews with key stakeholders; market analyses to assess edible oils in markets and focus groups as well as surveys with consumers to ascertain their perceptions and practices related to edible oils.

Setting: Four settings in Myanmar (upper income urban; lower income urban; middle-income urban; lower income rural).

Participants: Key stakeholders ( $n$ 12) from government, trade bodies and civil society organisations were included in the interviews. Women from each of the regions participated in four focus groups ( $n 32)$, and a convenience sample of male and female consumers participated in the surveys ( $n$ 362).

Results: We found mistrust of the oil sector overall. Poor production practices, leading to low yields, limit the economic viability of oil palm production in Myanmar and contribute to negative environmental (e.g. deforestation) and social outcomes (e.g. land conflicts). Consumers demonstrated low preferences for palm oil as compared with traditional oils from a taste, health and transparency perspective; however, they indicated that its relative low cost led to its purchase over other oils. Conclusions: The Burmese example suggests that there may be limited benefits, and significant costs, of investing in palm oil production in regions where there are coordinating disincentives from a sustainable diets perspective. However, if oil palm cultivation is to continue, there are opportunities to improve its economic viability and environmental sustainability.
\end{abstract}

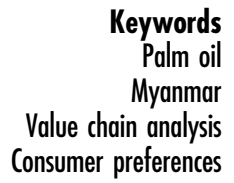

Sustainable diets encompass health, environmental, social and economic dimensions of the way in which food is produced, moves through the food system and is ultimately consumed $^{(1,2)}$. Given the breadth of dimensions that relate to sustainable diets, they are prone to trade-offs among their different elements. Industrial crop systems, such as oil palm production, can intersect with sustainable diets in multiple ways ${ }^{(3)}$. Understanding the trade-offs within these systems is complicated and will continue to be a challenge in terms of promoting sustainable diets in the face of land competition as well as climate variability and change, particularly in low- and middle-income countries ${ }^{(3)}$.

Palm oil is the most widely consumed edible oil globally ${ }^{(4)}$. It makes up $35 \%$ of the global edible oil supply ${ }^{(5)}$. As global demand for edible oils continues to rise, palm oil will likely play a prominent role in meeting demand ${ }^{(5)}$. It has been projected that oil palm production will need to increase by 25 million tons each year for the next decade to match rising global demand ${ }^{(6)}$. Currently, most palm oil $(\sim 85 \%)$ is produced in Indonesia and Malaysia ${ }^{(7)}$. 
However, due to the cultivation of increasingly less suitable lands and diminishing per hectare yields, these supply lines may be reaching peak production ${ }^{(8)}$. More significant future expansion of palm oil will likely occur in other parts of the world ${ }^{(9,10)}$.

As with most crops, there are economic, environmental, social and health trade-offs of producing and consuming palm oil ${ }^{(10)}$. Economic advantages of producing oil palm include its high yield compared with other edible oils which require substantially more land to produce the same amount of oil ${ }^{(7,10,11)}$, increased income and employment opportunities on farms, plantations and in processing mills and reduced poverty ${ }^{(10)}$. However, the oil palm boom has generated criticism related to the environmental and social consequences of its increased production ${ }^{(10)}$. Its production is associated with increased air pollution due to the burning of peat, land degradation, water pollution and significant losses in biodiversity associated with the clearing of forests $^{(10,12,13)}$.

From a nutrition standpoint, palm oil contains a high proportion of saturated fat as compared with most other edible oils ${ }^{(14,15)}$. While red palm oil contains a high content of antioxidants, beta-carotene and vitamin $\mathrm{E}^{(16)}$, most of the palm oil consumed globally is refined, bleached and deodorised. Given that there is evidence to suggest that substituting palm oil for oils with more unsaturated fatty acids may be more healthful ${ }^{(17,18)}$, shifting consumption away from palm oil to unsaturated oils could improve diets and health outcomes. The WHO advises that 'unsaturated fats (e.g. found in fish, avocado, nuts, sunflower, canola and olive oils) are preferable to saturated fats (e.g. found in fatty meat, butter, palm and coconut oil, cream, cheese, ghee and lard)'(19). This messaging is consistent with food based dietary guidelines in nearly a third of countries globally ${ }^{(20)}$.

\section{Overview of Myanmar}

Indonesia and Malaysia produce the majority of palm oil globally. However, other countries, including Myanmar, have begun producing palm oil in order to reduce their reliance on imports from a food sovereignty perspective ${ }^{(21)}$. While sesame and groundnut oils were traditionally used in Burmese cooking, palm oil import has increased dramatically in Myanmar since the $1990 \mathrm{~s}^{(22,23)}$. Moreover, in the past two decades, Myanmar has incentivised investment in domestic palm oil production in the southern Tanintharyi region, an area of rich biodiversity and home to several ethnic minorities ${ }^{(24-29)}$. Tanintharyi's palm oil plantation development and expansion has reduced forest cover by over 70000 hectares from 2002-2014 alone ${ }^{(30)}$. The challenges introduced from this rapid change in land use due to oil palm development highlight the complex socio-ecological factors at play.
As Myanmar, as well as other countries globally, expands oil palm production, understanding the economic, health, social and sustainability trade-offs of these shifts, along with their drivers, will allow for the identification of more nuanced policy interventions for private sector innovation aimed at creating synergies among health, environmental and economic goals. Using an enhanced value chain analysis, this study examines the incentives and disincentives for the sustainable production and consumption of palm oil by conducting a case study of Myanmar and identifies potential intervenable points in the value chain to improve its economic viability, sustainability and health implications.

\section{Methods}

\section{Conceptual underpinning and metbodological approach}

The conceptual underpinning of our approach centered on the various elements of sustainable diets. Given the increased global attention being placed on sustainable diets, we used an enhanced form of value chain analysis that incorporated both health and sustainability considerations. We adopted a broad view of sustainability that includes environmental (e.g. greenhouse gas emissions, water use, deforestation, etc.) and socio-cultural (e.g. consumer preferences, equity issues, labor conditions, land tenure, etc.) considerations based on a previously published sustainable diets policy analysis framework ${ }^{(31)}$. Supplemental Figure 1 provides an overview of the dimensions of sustainable diets considered in this manuscript.

Our methodological approach was informed by a combination of several value chain analysis methods (e.g. consumption-oriented food supply chain analysis, political economy analysis, etc. $)^{(32)}$, with a particular emphasis on the value chains for nutrition framework developed by Gelli et al. ${ }^{(33)}$ for identifying, designing and evaluating interventions. It was conducted in four main steps: (1) analysing the macro-level food system context as it relates to edible oils in Myanmar; (2) characterising palm oil consumption patterns and identifying constraints to consuming alternative oils; (3) characterising the health, environmental and social properties of oil palm production and consumption and (4) identifying intervenable points in the value chain to strengthen the edible oil sector in an effort to support sustainable diets. A combination of document analysis, semi-structured interviews with key stakeholders, focus groups with consumers and market and consumer surveys were conducted. Data collection was conducted between June-August 2017. This study was approved by the Johns Hopkins University institutional review board. Local study partners included a conservation non-governmental organisation and a survey research organisation. All study participants provided informed oral consent to participate in the study. 


\section{Semi-structured interviews and document analysis}

The lead author conducted semi-structured interviews with key stakeholders ( $n$ 12) who had expertise related to Myanmar's palm oil sector from government (agriculture, nutrition and health), civil society organisations and nongovernmental organisations (agriculture, sustainability and consumer rights organisations) and trade bodies (oil processing, retail and trade and food science and technology). Preliminary document analysis, a formative field visit by the authors (S.M.D. and J.F.) where they met and informally interviewed several stakeholders $(>15)$ from United Nations agencies, non-governmental organisations, civil society organisations, academia, etc., and local non-governmental organisation partners who were directly engaged in the palm oil sector helped to identify initial stakeholders. Additional stakeholders were identified through snowball sampling. We continued to identify additional interviewees until the point that we were not obtaining any new information from the interviews that we conducted. We selected interviewees based on their knowledge of the sector and their expertise related to different steps of the supply chain. While we attempted to interview firms directly involved in the production and processing of palm, we were unable to secure interviews with them. The interview guide was based on the different steps in the palm oil value chain and was tailored to the individuals' areas of expertise. Supplemental Table 1 provides an overview of the interview guide, which was subsequently tailored to the value chain actor being interviewed. All but three of the interviews were recorded and transcribed verbatim. For those interviews that were not recorded, detailed notes were taken during the interview. We complemented the interviews with document analysis of policy documents, reports on the palm oil sector and with existing data from the FAO on edible oil imports and exports.

\section{Focus groups with consumers}

We conducted consumer focus groups in four settings in Myanmar (upper-income urban township of Yangon; lower income urban township of Yangon; middle-income urban township in the Southern Myanmar town of Dawei; lower income rural village in the country's dry zone of Magway) to better understand consumers' consumption patterns, preferences and their decision making related to edible oils. Additional details regarding the focus groups, market and consumer surveys have been previously published ${ }^{(34)}$. In each of the study settings, our local partner would purposively select focus group participants with the assistance of community leaders to ensure variation in terms of age of participants ${ }^{(34)}$. In the case of the upper-income urban township in Yangon, additional sampling techniques were needed given the difficulty in identifying potential participants. In this case, women were identified through the existing networks of our local partner. Women were asked whether they made food purchasing decisions within their household prior to participating in the focus group - all women approached to participate in the focus group indicated that they did. A semi-structured focus group guide that included questions related to oil consumption, purchase and preferences was used (see online Supplemental Table 2). Each focus group contained eight women participants ( $n$ total 32) (age range 21-61 years; mean 40 years) who made food purchasing decisions within their household. Focus group participants received an incentive for participation (20 000 Burmese Kyat; equivalent to approximately US $\$ 15$ ) based on recommendations from local partners. A trained Burmese facilitator guided the focus group discussions. In addition to the focus group facilitator, an additional researcher took detailed notes of the focus group discussions. The focus group discussions were recorded, transcribed verbatim and translated into English for data analysis.

\section{Market surveys}

We conducted market surveys at five markets in each of the four study settings. A total of twenty market surveys were conducted in the markets that focus group participants mentioned they frequented the most. We obtained the price of each oil (sesame, groundnut, palm, sunflower, vegetable and soybean) from three different vendors in each market. However, in some cases, specific oils were not available in the market. We also asked whether the oil was sourced domestically or was imported and examined whether or not they contained labels.

\section{Consumer surveys}

A total of 400 consumer surveys were completed (with men and women) at the twenty markets surveyed (see online Supplemental Table 3 for overview of socio-demographic characteristics). However, we removed thirty-eight survey respondents who did not reside in the study settings (total sample $n$ 362). Two enumerators were stationed at the markets and asked consumers over the age of 18 years to participate in the study as they passed by, which is a typical approach in street intercept surveys ${ }^{(35)}$. Intercept surveys were conducted outside of the markets with consumers who were attending the market. Participants received a nominal incentive for participation (1500 Burmese Kyat; equivalent to approximately US\$1). Consumer surveys included questions related to oil preferences and consumption, the primary oils used for cooking at home, the reason for using that oil (i.e. taste, price, availability, convenience, health or other) and which oil they considered the cheapest, the tastiest and the healthiest.

\section{Analysis}

All data sources were combined and examined at each step of the palm oil value chain - inputs; production; 
processing; storage, distribution and trade; retail; and consumption - to examine the incentives and disincentives related to sustainable palm oil production and consumption. The interview transcripts, focus group transcripts, detailed notes and documents were open-coded and organised based on key themes related to the incentives and disincentives for palm oil production and consumption throughout the steps of the value chain using NVivo (version 11.4.2). We then triangulated these data from the quantitative data obtained from the consumer and market surveys. To identify points for intervening throughout the supply chain, we first determined where the bottlenecks in the current supply chains were, and subsequently identified potential interventions to address them based on the interviews, focus groups and market analyses. References are provided within the results section to denote when documents, rather than interviews, focus groups or surveys, are the source of the information described. Interview and focus group quotes are used throughout the results section to illustrate key themes derived from the qualitative data.

In order to examine incentives and disincentives for palm oil consumption at the consumer level, we used descriptive statistics to describe preferences for edible oils and their perceived characteristics. Differences in edible oil preferences based on study setting were examined using chi-squared tests. In order to assess market level incentives and disincentives for palm oil purchase, we used descriptive statistics to examine their availability and price. All quantitative analyses were conducted using SPSS (version 24). A $P$-value of $<0.05$ was used to denote statistical significance.

\section{Results}

\section{Overview of palm oil value chain}

Figure 1 provides an overview of the drivers of the palm oil sector in Myanmar and its consequences, based on our study findings. There were several cross-cutting drivers related to the edible oil sector in Myanmar that have consequences for the palm oil supply chain. Key informant interviewees described a lack of transparency, including as it relates to the availability of palm oil production statistics in the country, as well as traceability throughout edible oils supply chains, which makes it difficult for consumers to know what they are purchasing and the source. In addition, there continues to be governance challenges (including corruption) and political instability in the country. Along with these challenges comes a lack of enforcement capacity to improve transparency in the edible oil supply. Lastly, a lack of strong infrastructure (e.g. roads) plagues the edible oil sector, as well as the agricultural sector more broadly, at each step of the supply chain.

In recognising its reliance on imported palm oil, the Myanmar Government adopted a self-sufficiency policy in the early 2000s. The self-sufficiency policy centered on the Tanintharyi region of Southern Myanmar becoming the 'oil bowl' of the country by investing in palm oil production. However, palm oil production in the region has had limited success due to supply chain constraints that are unique to Myanmar, including suboptimal production practices and low yields as compared with neighbouring palm oil producing countries. Although there are a small number of companies that are generating profits, in most cases, the yields and quality of the palm oil produced are low. Based on focus group discussions and market surveys, consumers prefer the oils that have traditionally been produced in the country (groundnut and sesame), yet the productivity of those oils is low given numerous constraints (e.g. lack of irrigation, low quality seed, antiquated machinery).

Table 1 provides an overview of the key challenges across the Burmese palm oil value chain that influence its production, the way it moves along the value chain, as well as its consumption and whether they have a positive, negative or neutral consequence on the economic viability of the sector, sustainability and human health. We describe the interrelationship between these opportunities and challenges and the trade-offs they create below.

\section{Domestic palm oil production}

The government provided several incentives to companies to establish oil palm plantations in the Tanintharyi region; however, it has had limited success. It was suggested in the stakeholder interviews that some companies cleared the land to profit from logging rather than oil palm production. As one stakeholder said: 'But no need to grow ... no need to grow palm oil. It's very difficult and very hard work. Just using that kind of opportunity is much much better (agronomist, palm oil expert). Although interviewees indicated that there are a small number of companies generating profits in Myanmar, in most cases, the yields and quality of the palm oil produced are low due to several reasons described in Table 1. Many of the companies that entered into the palm oil sector with government-provided land concessions did not have prior experience growing palm oil. This led to suboptimal production practices and, in some cases, limited investment to improve those practices. As one stakeholder from the agriculture sector stated: 'That's why, even though they want to develop the project, but because of the lack of support, they can do nothing.'

Interviewees indicated that while companies have grappled with production challenges related to increasing yields, they have also been dealing with the social and environmental issues associated with the palm oil sector in Myanmar. Land tenure is one of the main social challenges related to palm production in the area. There have been accusations of land grabbing by companies and expansion beyond permitted areas in some parts of the Tanintharyi region, creating tension between the palm oil companies 
Steps of value chain
Outcomes

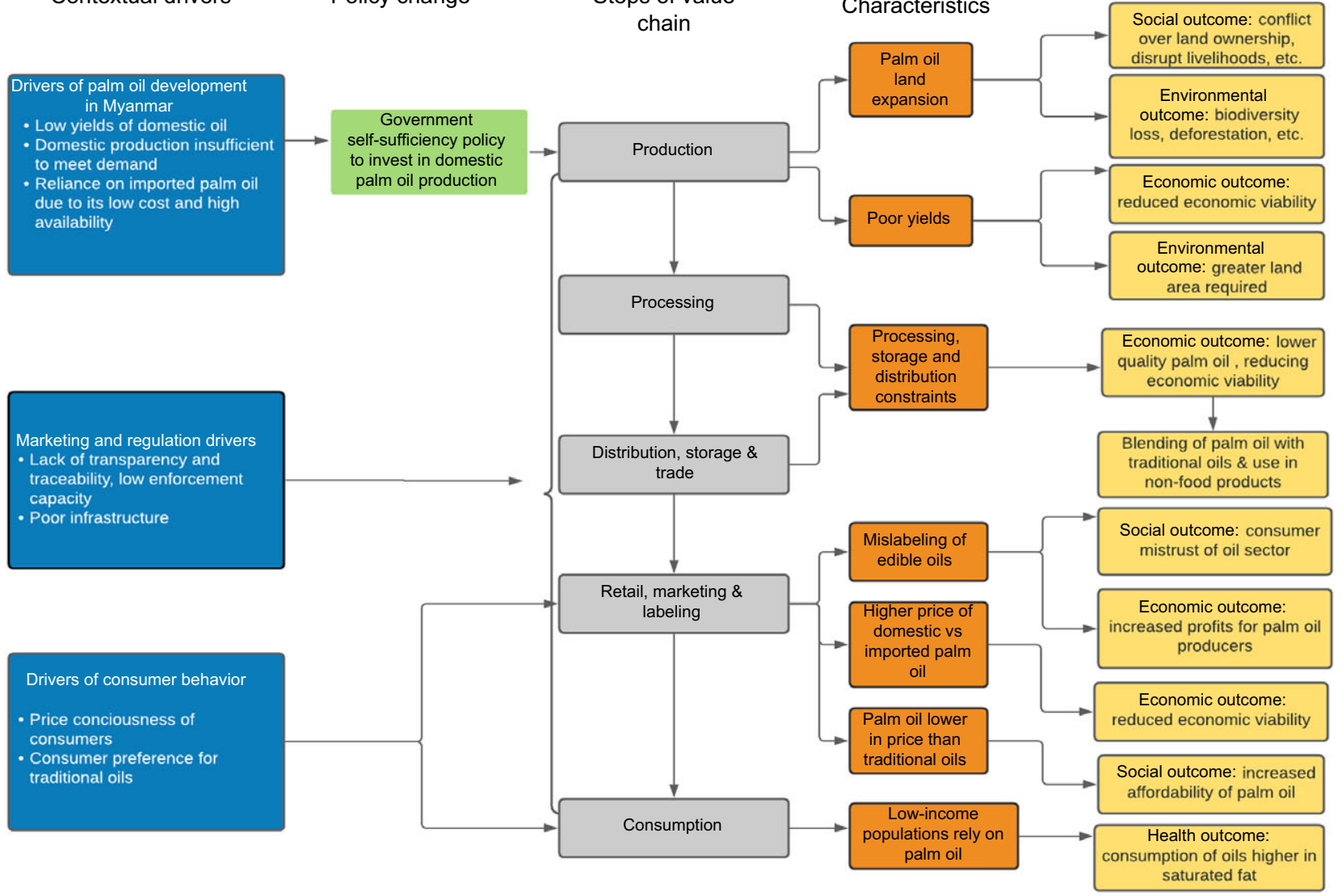

Fig. 1 (colour online) An overview of the edible oil sector in Myanmar

and local communities. As one stakeholder from a sustainability non-government organization (NGO) said: 'Your basic human right to livelihood. You have the right to protect your environment. You have the right to have property and the plantations. You have the right to ask compensation. Since they have grabbed your land.'

One potential benefit of increasing palm production in the area is employment creation. However, the majority of palm oil plantation laborers are migrant workers, many of whom live under poor conditions ${ }^{(36)}$. Interviewees indicated that the government 'don't want to get involved in this issue' given the complexity and the difficulty in finding solutions.

In Myanmar, forests have been cleared to plant palm $\mathrm{oil}^{(37,38)}$. However, given the lack of knowledge related to appropriate conservation practices, there has been total clearing of forests: 'We just know how to grow and how to harvest. That's all. But ourpeople do not have enough experience for environmental conservation. And we don't have enough knowledge. We have very little knowledge of as to how to conserve the environment. Even we don't know what is high conservation value? We also don't know about as to how to conserve the biodiversity' (agronomist, palm oil expert). To address the environmental concerns related to palm production, there has been a push towards 'sustainable' production practices as part of the Roundtable on
Sustainable Palm Oil (RSPO). In Myanmar, interviewees indicated that it was premature to seriously consider sustainability. As one oilseed industry expert indicated: 'Your question is very advance. Our people cannot think that. They are just thinking for their finances.' There was a perceived trade-off between investing in more sustainable practices and ensuring the economic viability of the sector.

\section{Distribution, storage and trade constraints}

One of the main challenges related to better understanding the distribution of palm oil in Myanmar is the lack of traceability. Little is known about how much palm oil is produced in the country, or what happens to it once it has been produced. One interviewee with knowledge of the sector estimated that approximately $40 \%$ of the palm oil produced in the country was being sold as cooking oil and the other $60 \%$ was being sold in processed foods and for industrial uses such as soap, candles, etc. The majority of the lower quality oil was being used for the latter. However, official statistics about the total production of palm oil and its uses do not exist.

At the same time that palm oil is being produced domestically, the country is importing large quantities of palm oil. 


\section{Public Health Nutrition}

Table 1 Overview of the key challenges across the palm oil value chain in Myanmar and their consequences

\begin{tabular}{|c|c|c|c|c|c|}
\hline \multirow[b]{2}{*}{$\begin{array}{l}\text { Steps of value } \\
\text { chain }\end{array}$} & \multirow[b]{2}{*}{ Key challenges } & \multirow[b]{2}{*}{ Description } & \multicolumn{3}{|c|}{ Consequence } \\
\hline & & & $\begin{array}{l}\text { Economic } \\
\text { viability }\end{array}$ & Sustainability & $\begin{array}{l}\text { Human } \\
\text { health }\end{array}$ \\
\hline \multirow[t]{9}{*}{ Production } & $\begin{array}{l}\text { Suboptimal agro-climatic condi- } \\
\text { tions }\end{array}$ & $\begin{array}{l}\text { - Inconsistent rainfall } \\
\text { - Topography of land (e.g. hills) } \\
\text { - Soil acidity }\end{array}$ & $\downarrow$ & $\downarrow$ & - \\
\hline & $\begin{array}{l}\text { Suboptimal management practi- } \\
\text { ces }\end{array}$ & $\begin{array}{l}\text { - Inappropriate application of fertilizer } \\
\text { - Lack of financial capital to invest in plantations } \\
\text { - Lack of experience among plantation owners }\end{array}$ & $\downarrow$ & $\downarrow$ & - \\
\hline & Lack of electricity & - Electricity challenges create bottlenecks for refineries & $\downarrow$ & - & - \\
\hline & $\begin{array}{l}\text { Concessions to private sector to } \\
\text { engage in palm oil production }\end{array}$ & $\begin{array}{l}\text { - Land concessions } \\
\text { - Subsidies on diesel, duty-free import of machinery, waiving of commercial tax }\end{array}$ & $\uparrow$ & $\downarrow$ & - \\
\hline & Misuse of concessions & - Clearing of land for logging rather than palm oil production & $\uparrow$ & $\downarrow$ & - \\
\hline & Relatively low productivity levels & $\begin{array}{l}\text { - Yields lower in Myanmar compared with Indonesia and Malaysia } \\
\text { - Higher cost of production in Myanmar }\end{array}$ & $\downarrow$ & $\downarrow$ & - \\
\hline & Land tenure conflict & $\begin{array}{l}\text { - Accusations of land grabbing and expansion of forest clearing beyond their permits by palm oil } \\
\text { companies } \\
\text { - Difficulty for indigenous populations to provide documentation of their land rights } \\
\text { - Tensions between community members and palm oil companies } \\
\text { - Production in historical conflict areas }\end{array}$ & $\uparrow$ & $\downarrow$ & - \\
\hline & $\begin{array}{l}\text { Majority of labour force on plan- } \\
\text { tation are migrant workers }\end{array}$ & $\begin{array}{l}\text { - Low quality living conditions for migrant workers } \\
\text { - Limited local employment opportunities }\end{array}$ & $\uparrow$ & - & $\downarrow$ \\
\hline & Limited conservation efforts & $\begin{array}{l}\text { - Focus on sustainable palm oil production viewed as being premature } \\
\text { - RSPO certification deemed too difficult for most companies } \\
\text { - Limited knowledge related to conservation practices }\end{array}$ & $\uparrow$ & $\downarrow$ & - \\
\hline \multirow[t]{2}{*}{ Processing } & Limited processing capacity & $\begin{array}{l}\text { - Insufficient processing facilities and the quality of those facilities were considered poor } \\
\text { - Few of the companies in Myanmar have their own processing plants, which means they rely on selling } \\
\text { their fruit to larger companies to process them } \\
\text { - Limited refineries to process crude oil into refined oil } \\
\text { - Long distances and poor roads create barriers to refinement }\end{array}$ & $\downarrow$ & $\downarrow$ & - \\
\hline & $\begin{array}{l}\text { Blending of palm oil with other } \\
\text { oils }\end{array}$ & $\begin{array}{l}\text { - Palm oil blended with other oils, such as groundnut or sesame, and being sold in markets without } \\
\text { accurate labelling }\end{array}$ & $\uparrow$ & - & - \\
\hline \multirow[t]{2}{*}{$\begin{array}{l}\text { Distribution, } \\
\text { storage and } \\
\text { trade }\end{array}$} & Lack of traceability & $\begin{array}{l}\text { - Little is known about how much palm oil is produced in the country, or what happens to it once it } \\
\text { has been produced. } \\
\text { - There are no official statistics regarding palm oil production in Myanmar }\end{array}$ & & & \\
\hline & Reliance on palm oil imports & $\begin{array}{l}\text { - Insufficient production of domestically produced oils } \\
\text { - Relatively high cost of domestically produced foods }\end{array}$ & $\uparrow$ & - & $\downarrow$ \\
\hline \multirow[t]{2}{*}{ Retail } & Low cost of palm oil & - Domestically produced palm oil more costly than imports & $\uparrow$ & - & - \\
\hline & $\begin{array}{l}\text { Lack of enforcement of adulter- } \\
\text { ated oils }\end{array}$ & $\begin{array}{l}\text { - Lack of capacity among the Myanmar FDA for monitoring and enforcement } \\
\text { - High cost of testing oils to ensure proper labelling seen as a barrier to scaling up enforcement to ensure } \\
\text { that the oils sold are unadulterated and that labelling reflects the true contents of oil }\end{array}$ & $\uparrow$ & - & $\downarrow$ \\
\hline \multirow{2}{*}{$\begin{array}{l}\text { Marketing \& } \\
\text { labelling }\end{array}$} & Inaccurate labelling of oils & - Oils that were labelled as vegetable oils in the country were also predominantly palm oil & $\uparrow$ & - & - \\
\hline & Lack of labels & $\begin{array}{l}\text { - Many oils, particularly domestically produced, lack labels } \\
\text { - Oils purchased as 'loose' in informal market }\end{array}$ & $\uparrow$ & - & - \\
\hline
\end{tabular}


Nearly all the edible oil imports in Myanmar consist of palm oil (see online Supplemental Fig. 2). Our analyses of the oils available in the markets showed that over half of the palm oil being sold was domestically produced, while the majority of 'vegetable oil' was imported (although it is likely that it mostly consisted of palm oil), and the traditional oils such as sesame and groundnut were all produced domestically (Fig. 2). In focus group discussions, consumers living in the Tanintharyi region of Myanmar, where palm oil is produced, indicated greater trustworthiness of the quality of imported oils from Thailand.

\section{Processing constraints}

One of the main bottlenecks identified in the supply chain of domestically produced palm oil in Myanmar was processing capacity. There were insufficient processing facilities, and the quality of those facilities was considered poor. Fresh fruit bunches need to be processed within $24 \mathrm{~h}$ of being picked to create crude palm oil, which is subsequently refined further (i.e. secondary processing to refine, bleach and deodorise) prior to being consumed as cooking oil. Few of the companies in Myanmar have their own processing plants, which means they rely on selling their fruit to larger companies to process them. Moreover, there were few refineries in the Tanintharyi region for secondary processing of oils. These refineries were primarily based in the Yangon region rather than in the region in which the palm oil is grown. One interviewee indicated that this was due to more reliable electricity in the Yangon area as well as economic incentives from the government, including land concessions. However, the distance between Yangon and Tanintharyi was considered significant $(\sim 1000 \mathrm{~km})$. The long distance in addition to poor roads and infrastructure served as barriers to processing. Interviewees indicated that these challenges jeopardised the quality of the palm oil that was subsequently processed.

All interviewees indicated that palm oil was being blended with other oils, such as groundnut or sesame, and being sold in markets without accurate labelling. As one interviewee from a sustainability NGO stated: 'They are calling it groundnut when its groundnut mixed with palm oil.' Interviewees indicated that 'Because of this technique they can get the profit' (agronomist, palm oil expert). Interviewees stated that oils that were labeled as vegetable oils in the country were also predominantly palm oil. They also acknowledged that there was little disincentive for blending of oils without properly labelling them, given the lack of enforcement and insignificant fines.

\section{Retail, promotion and labelling constraints}

The reliance on informal markets has made it easier to sell blended edible oils. A lack of capacity among the Myanmar FDA for monitoring and enforcement was also identified through interviews. The high cost of testing oils to ensure 
Panel A: Oil source

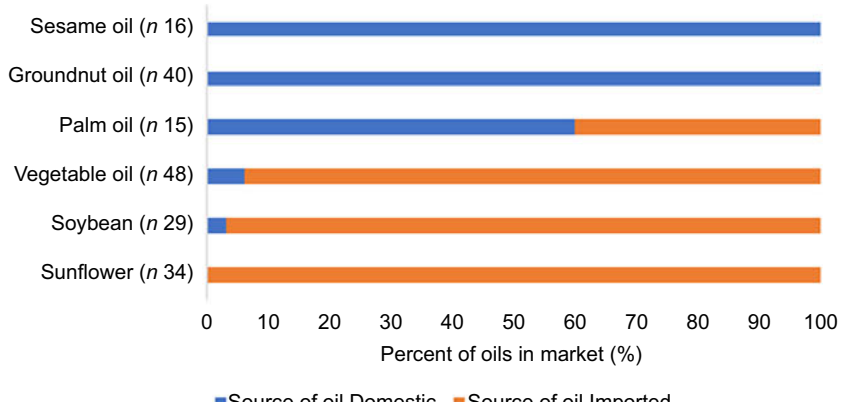

=Source of oil Domestic $=$ Source of oil Imported

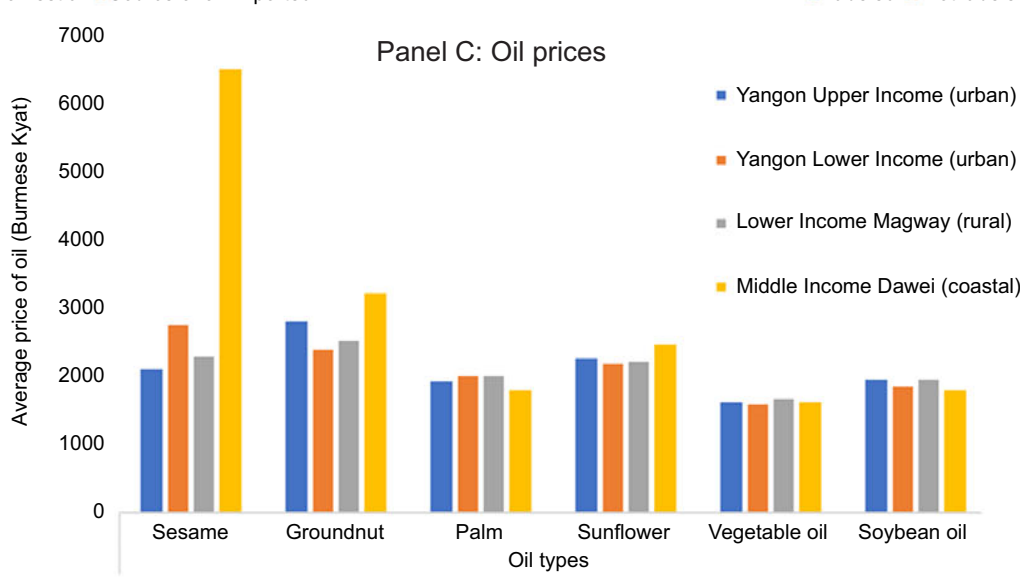

Panel B: Labelling

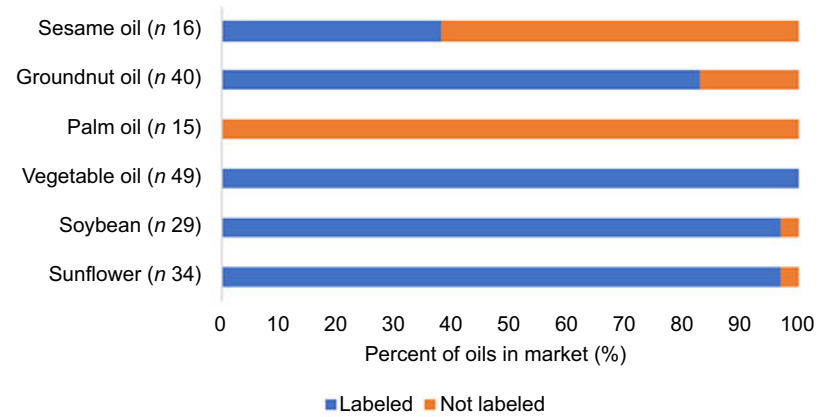

Fig. 2 (colour online) An overview of the source and use of labels among oils examined in markets ( $n 20)$ in four regions of Myanmar. Note: Vegetable oil refers to oil labelled as 'vegetable' oil without information about the specific oils included

accurate labelling was also seen as a barrier to scaling up enforcement to ensure that the oils sold are unadulterated and that labelling reflects the true contents of oil.

Many of the oils sold in Myanmar were unbranded, lacking labels and packaging, including those that are imported. In the market analyses, we found that none of the palm oil available within the markets we examined contained labels, while all, or nearly all, of the vegetable, soybean and sunflower oils, the majority of which were imported, contained branded labels (Fig. 2). Moreover, the oil purchased at smaller retailers was still often sold 'loose' (i.e. not in a container). As one interviewee from a food safety NGO said: 'Somebody come to the small shop, they bring their own container and then the seller put in that, they carry it away and they use.'

\section{Consumption of palm oil}

Figure 3 provides an overview of consumers' preferences for different oils based on the consumer surveys. There were significant differences in the taste preferences for different oils based on study setting, with both upper- and lower-income urban, as well as those living in the Tanintharyi region, preferring groundnut oil while rural consumers, who lived in the sesame growing region, preferred sesame oil $(P<0$ 001; Panel A). The oils typically used for cooking also varied significantly among regions $(P<0$ 001), with the highest proportion of participants using palm oil as their cooking oil in the lower income neighbourhood in Yangon (Panel B). A similar pattern was found for the perceived healthfulness of the different oils, where sesame was perceived to be the healthiest oil among rural consumers, while groundnut was considered the healthiest among consumers in the other study settings. With the exception of palm oil and vegetable oil, health was the main factor influencing use of a given type of edible oil (see online Supplemental Fig. 3). Consumers most often reported cooking with palm oil because of its price, availability and convenience, with very few consumers choosing palm oil for its healthfulness.

We found a considerable amount of mistrust in the entire edible oil sector. As an interviewee from a consumer organisation said: 'We all are worried whether we are having a safe oil or not.' For this reason, oils that were labelled as having 'FDA approval' were seen as being more trustworthy. Based on focus group discussions, some consumers attributed the mixing of oils without appropriate labelling of the contents as 'occurring because of the greed' of companies (Yangon, upper-income). The trade-off between quality and price was also described in the consumer focus group discussions, particularly among lower income participants. As one focus group participant from a rural low-income village said: 'Mixed oil is not good for health as groundnut oil and sesame oil. I can afford only the relatively cheap oil and so I have to use less expensive 

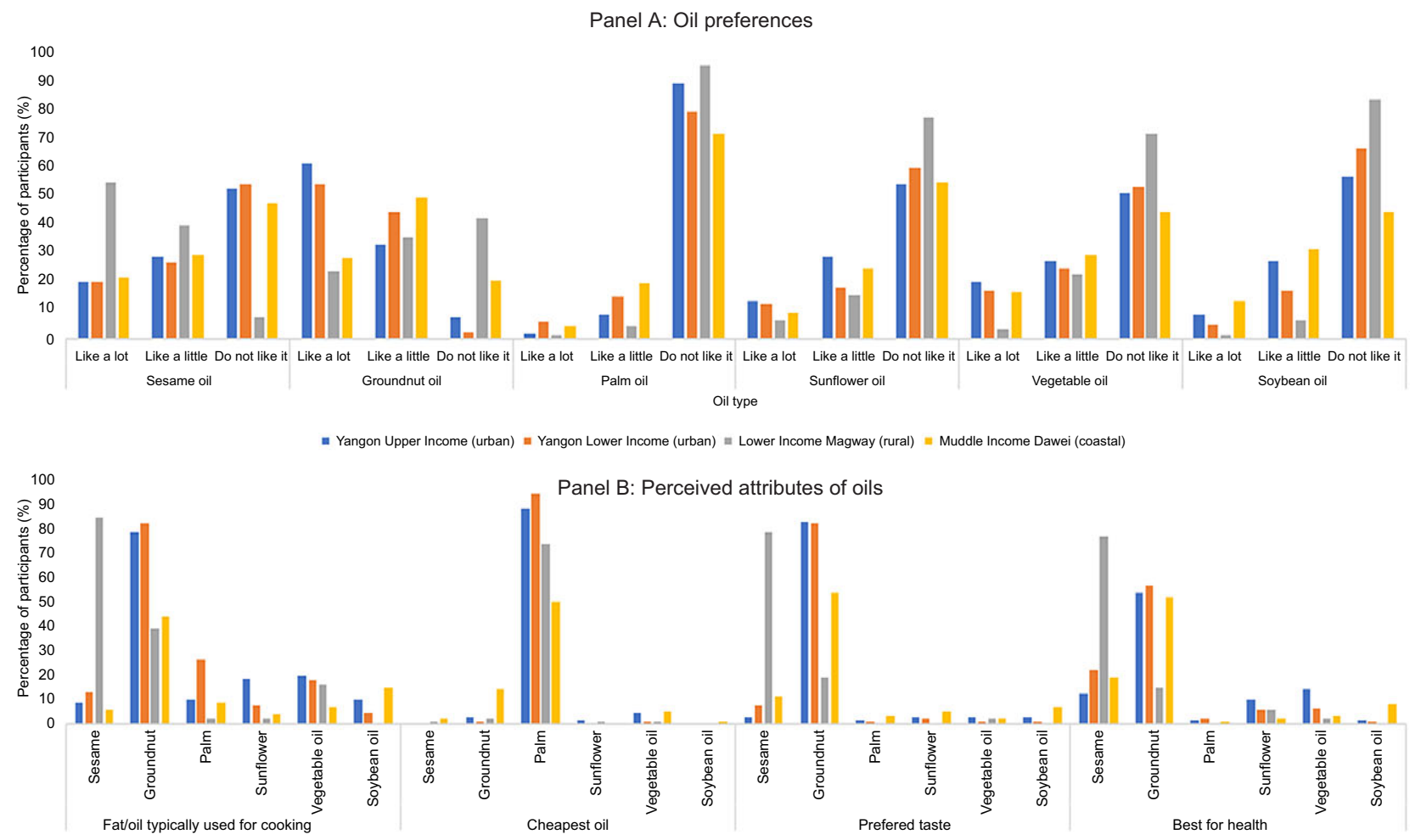

Fig. 3 (colour online) An overview of edible oil preferences and perceived attributes in four communities in Myanmar. Significant differences in edible oil preferences and oils typically used using Chi-squared test $(P<0.01)$

mixed oil although its taste is not so good. I consume mixed oil only because of its price and my income.'

\section{Entry points for interventions to improve sustainability of edible oils}

Based on the findings of the interviews, document analysis, market surveys, consumer surveys as well as focus group discussions, Table 2 provides an overview of potential points for intervening throughout the supply chain and their consequences regarding the sector's economic viability, sustainability (including environmental and socio-cultural considerations) and human health. Many of the levers for intervening in the food supply apply to both palm oil as well as traditional oils produced within the country. Importantly, many trade-offs were identified as it relates to intervening to support increased palm oil production within Myanmar demonstrating the potential pitfalls of continuing to invest in this sector. However, given that Myanmar has shown no indication of easing oil palm cultivation, bolstering sustainability moving forward is imperative not only for the Burmese market but because of how interconnected health, environment and trade are with palm oil.

\section{Discussion}

Although there are often trade-offs from a sustainable diets perspective of increasing palm production and consumption, we found several coordinating disincentives for its production and consumption in Myanmar. Namely, relatively low productivity levels hinder the sector's economic viability while consumers report low preferences for its consumption as compared with traditional oils. While our analysis suggests that diverting investment from palm oil to traditional oils in Myanmar may be warranted, we also highlight how the palm oil sector could be strengthened given that it is expected that oil palm cultivation will expand to regions around the world with suboptimal climatic conditions ${ }^{(10)}$. For those countries, there are lessons to be learned from Myanmar's experience to better support sustainable diets.

\section{Economic and environmental considerations}

Countries such as Myanmar that invest in domestic palm oil production will need to identify ways of increasing the economic viability of the sector while weighing the environmental, social and health costs associated with its production and consumption. Although a small number of companies in Myanmar are profiting from palm oil production, many of them are not, and the sector is not as economically viable as in Indonesia and Malaysia where the palm oil industry has led to large-scale economic growth $^{(10,39)}$. However, for those companies where palm oil production is profitable, there is a trade-off between profitability and investing in more environmentally sustainable practices. The trade-off between producing 
Public Health Nutrition

Table 2 An overview of entry points to improve the sustainable production and consumption of oils in Myanmar

\begin{tabular}{|c|c|c|c|c|c|c|c|}
\hline \multirow[b]{2}{*}{$\begin{array}{l}\text { Steps of } \\
\text { value chain }\end{array}$} & \multirow[b]{2}{*}{ Points for intervening in supply chain } & \multirow{2}{*}{$\begin{array}{l}\text { Applies to } \\
\text { traditional } \\
\text { oils }\end{array}$} & \multirow{2}{*}{$\begin{array}{l}\text { Applies to } \\
\text { palm oil } \\
\text { production }\end{array}$} & \multicolumn{3}{|c|}{ Potential consequences } & \multirow[b]{2}{*}{ Potential trade-offs and synergies } \\
\hline & & & & $\begin{array}{l}\text { Economic } \\
\text { viability }\end{array}$ & Sustainability & $\begin{array}{l}\text { Human } \\
\text { health }\end{array}$ & \\
\hline \multirow{8}{*}{$\begin{array}{l}\text { Inputs and } \\
\text { agricul- } \\
\text { tural pro- } \\
\text { duction }\end{array}$} & Increased access to credit & $x$ & $x$ & $\uparrow$ & $\uparrow$ & $\uparrow$ & - Improved access and use of inputs could increase \\
\hline & Investment in R\&D & $x$ & $\begin{array}{l}x \\
x\end{array}$ & 1 & $\downarrow$ & $\downarrow$ & economic viability because of potential increase in \\
\hline & $\begin{array}{l}\text { Increased access to irrigation } \\
\text { Improved fertilizer application }\end{array}$ & $\begin{array}{l}x \\
x\end{array}$ & $\begin{array}{l}x \\
x\end{array}$ & & & & yields, while also putting additional stress on the envi- \\
\hline & $\begin{array}{l}\text { Improved fertllizer application } \\
\text { Access to improved farming machinery and technology }\end{array}$ & $\begin{array}{l}x \\
x\end{array}$ & $\begin{array}{l}x \\
x\end{array}$ & & & & ronment if not done in a sustainable way. \\
\hline & & & & & & & $\begin{array}{l}\text { - Improved inputs could lead to palm oil expansion leading } \\
\text { to negative social and environmental outcomes. } \\
\text { Increased palm oil availability and affordability may } \\
\text { reduce consumption of more healthful traditional oil } \\
\text { (substitution effect). }\end{array}$ \\
\hline & Stronger land tenure laws (including enforcement) & $\mathrm{x}$ & $\mathrm{x}$ & $\downarrow$ & $\uparrow$ & - & $\begin{array}{l}\text { - Customary land rights of local communities would be } \\
\text { more sustainable in terms of protecting their liveli- } \\
\text { hoods, enabling smallholder production, etc. } \\
\text { - Protecting customary land rights of local communities } \\
\text { could reduce economic viability of palm oil sector. }\end{array}$ \\
\hline & $\begin{array}{l}\text { Improved knowledge transfer of best practices (including } \\
\text { feasible conservation practices) for producing palm oil } \\
\text { efficiently within the context of the agro-climatic condi- } \\
\text { tions in the Tanintharyi region }\end{array}$ & & $\mathrm{x}$ & $\uparrow$ & $\uparrow$ & $\downarrow$ & $\begin{array}{l}\text { - Improved knowledge transfer could increase both eco- } \\
\text { nomic viability and sustainability of oil palm production } \\
\text { through increased ecosystem services. } \\
\text { - Emphasis on conservation practices could increase } \\
\text { labour requirements, which has the potential to generate } \\
\text { more employment but also to further reduce economic } \\
\text { viability of oil palm production. }\end{array}$ \\
\hline & Limiting further palm oil production expansion & & $\mathrm{x}$ & $\downarrow$ & $\uparrow$ & $\uparrow$ & $\begin{array}{l}\text { Limiting further expansion of palm oil could reduce the } \\
\text { economic viability of the sector but lead to improve- } \\
\text { ments in terms of sustainability and health outcomes. }\end{array}$ \\
\hline \multirow{3}{*}{$\begin{array}{l}\text { Primary } \\
\text { process- } \\
\text { ing }\end{array}$} & $\begin{array}{l}\text { Investment/upgrading of processing facilities for small- } \\
\text { scale oil producers }\end{array}$ & $\mathrm{x}$ & $x$ & $\uparrow$ & $\uparrow$ & $\uparrow$ & $\begin{array}{l}\text { - This would increase the economic viability of the } \\
\text { broader edible oil sector and increase sustainability }\end{array}$ \\
\hline & $\begin{array}{l}\text { Incentives for investment in improved processing tech- } \\
\text { nology }\end{array}$ & $\mathrm{x}$ & $\mathrm{x}$ & & & & $\begin{array}{l}\text { through improved efficiency in terms of the proportion } \\
\text { of oil extracted from the seed, fruit, nut, etc. }\end{array}$ \\
\hline & Increasing FDA certification of oil mills & $\mathrm{x}$ & $\mathrm{x}$ & $\downarrow$ & - & $\uparrow$ & $\begin{array}{l}\text { - Increased FDA presence could reduce blending of oils } \\
\text { making palm oil less economically viable given that } \\
\text { current blending practices without accurate labelling } \\
\text { allow manufacturers to sell palm oil blended with tradi- } \\
\text { tional oils at a higher price. However, could improve } \\
\text { the quality of product that reaches consumer with the } \\
\text { potential to improve health outcomes. }\end{array}$ \\
\hline $\begin{array}{l}\text { Distribution, } \\
\text { storage } \\
\text { and trade }\end{array}$ & $\begin{array}{l}\text { Improvements in infrastructure (e.g. roads, electricity, } \\
\text { etc.) }\end{array}$ & $\mathrm{x}$ & $\mathrm{x}$ & $\uparrow$ & $\uparrow$ & $\uparrow$ & $\begin{array}{l}\text { - Improved infrastructure would increase economic } \\
\text { viability and sustainability of edible oils due to products } \\
\text { being moved more easily and quickly, with less waste. } \\
\text { - Could increase oil availability leading to variable health } \\
\text { outcomes if consumption patterns shift. }\end{array}$ \\
\hline \multirow[t]{2}{*}{ Retail } & $\begin{array}{l}\text { Improved labelling of oils (stronger regulation, clear indi- } \\
\text { cation of breakdown of blended oils, etc.) }\end{array}$ & $x$ & $\mathrm{x}$ & $\downarrow$ & & $\uparrow$ & $\begin{array}{l}\text { - Improved transparency could reduce economic viability } \\
\text { of firms that are mislabelling products and enable con- } \\
\text { sumers to make more informed decisions. }\end{array}$ \\
\hline & Improved enforcement of oil supply & $\mathrm{x}$ & $\mathrm{x}$ & $\downarrow$ & & $\uparrow$ & $\cdot$ \\
\hline Marketing & FDA certification logos & $\mathrm{x}$ & $\mathrm{x}$ & $\downarrow$ & & $\uparrow$ & - \\
\hline
\end{tabular}

Decrease in outcome; $\uparrow$ Increase in outcome; $\uparrow$ variable (increase or decrease) in outcom 
sustainably and profitability is also experienced in other palm oil growing countries ${ }^{(40,41)}$. In Thailand, although little of the palm oil produced is RSPO certified, it is most often produced by smallholder farmers, rather than large plantations, and cultivation has been primarily in areas formerly used for producing other $\operatorname{crops}^{(42)}$. This has led to less deforestation associated with oil palm production in Thailand as compared with other palm producing countries ${ }^{(42)}$. Countries that expand oil palm production in the future could adopt an approach similar to Thailand which can help to address some of the environmental and social (e.g. land conflict) trade-offs related to oil palm expansion.

\section{Social considerations}

The palm oil sector in Myanmar is plagued by issues related to the land rights of indigenous communities from the region, who often do not have documentation of their land holdings. This has also been observed in other palm oil producing regions globally ${ }^{(10,43)}$. Interviewees in our study indicated that given the complexity of this issue, the government was reticent to get involved. However, strong community engagement and governance structures are necessary in this context. One potential option for strengthening community engagement, alongside increased transparency with regard to land rights, is to invest in the smallholder production of palm oil, which has been done in Thailand ${ }^{(44)}$. In 2013, the Government of Indonesia recognised the constitutional rights of indigenous peoples to their lands and territories, including their collective rights over customary forests ${ }^{(45,46)}$. As countries move forward with palm production, these rights should be protected from the onset of oil palm expansion. In Myanmar, it will be unlikely that the palm oil sector will be able to gain the trust of the public without better engagement with local communities.

\section{Consumer considerations}

Perhaps the most significant trade-off related to palm oil being weighed is for consumers and their health. We found that consumers perceived palm oil as being unhealthy as compared with other oils. While there is some evidence to suggest negative health outcomes associated with palm oil consumption from a nutrition perspective, the evidence is somewhat mixed ${ }^{(47,48)}$. Despite the lack of convincing evidence linking palm oil consumption with negative health outcomes, our findings suggest that consumers have a strong dislike of palm oil. We found that consumers' preferences were more aligned with traditional oils as compared with palm oil but that the cost of those oils was often prohibitive. This is aligned with previous research that has shown food prices to influence diets among low-income population in Myanmar ${ }^{(49)}$. By improving productivity of these oils and strengthening processing and distribution, their affordability could increase. Given rapidly Westernising diets and homogeneity induced by industrial monoculture agricultural products like palm oil, supporting a return to traditional oil consumption may prove beneficial in other future palm oil markets as well.

\section{The need for better supply chain governance}

Supply chain governance needs to be strengthened in countries such as Myanmar who pursue oil palm expansion. Currently, there is little transparency in the palm oil supply chains in Myanmar as it relates to both imported and domestically produced oils. It is likely that this lack of transparency will intensify with the current political instability within the country and the recent shift away from democracy. Given the number of departments and ministries involved in the food supply chain, ensuring a more cohesive approach to monitoring and enforcement of the sector is important. Historically, the FDA has not had sufficient capacity to ensure the quality of the edible oil supply in the country, as is evident in other countries ${ }^{(50)}$. Nevertheless, more recently, the FDA has signalled that they will increase surveillance at borders, and they are building laboratory facilities in order to be able to test foods ${ }^{(51)}$. Building the technical and human resource capacity of the FDA is necessary but needs to be coupled with strong governance aimed at increasing transparency along the entire supply chain. This will also help to address consumer concerns related to the trustworthiness of edible oils. With strong labelling regulation as well as monitoring and enforcement of that regulation, trustworthiness of the edible oil sector could be improved ${ }^{(52)}$.

\section{The need for investment by both the private sector and government}

As with improved governance, if countries such as Myanmar expand palm oil production, increased investment in the sector is required. Given the low productivity levels of palm oil in Myanmar as compared with other countries, investment by the private sector is needed in order to adopt improved production strategies and technologies. This will likely be true in other countries that pursue oil palm expansion in less favourable climatic conditions. Access to credit and technology will be needed in these settings ${ }^{(10)}$, particularly for smallholder producers. At the same time, investment in R\&D by both the private sector and the government could help improve production practices of palm oil as well as traditional oils. The private sector also needs to invest in increased storage and processing facilities to reduce bottlenecks in the distribution of palm oil once the fresh fruit bunches have been picked, given the time sensitivity. Investment in road infrastructure as well as providing incentives for upgrading processing facilities for traditional oils is also necessary to streamline their supply chains. 


\section{Limitations}

This study had several limitations. We were limited by a relatively small sample of key stakeholders. While we intended to conduct interviews with stakeholders representing each of the steps of the value chain, we were unable to secure interviews with palm oil producers, indigenous persons being displaced by oil palm production as well as other key groups. Our study was also limited by our lack of analysis of samples taken from oils sold in markets to triangulate data from interviews and market surveys. Lastly, we were also limited by our lack of consumption data.

\section{Conclusions}

This value chain analysis proposes four key findings. First, given high cost of production and low oil palm yields, the economic viability of Myanmar's palm oil industry is uncertain. Second, the environmental and social costs of industrial palm oil expansion are significant and settings such as Myanmar's biodiverse and ethnically diverse Tanintharyi region are especially vulnerable. Third, large gaps in governance and monitoring of Myanmar's edible oil sector contribute to data scarcity and misaligned incentives that make it extremely difficult to identify supply chain bottlenecks. Lastly, consumers have expressed strong preferences for traditional oils such as groundnut and sesame, casting into doubt the efficacy of strengthening palm oil supply chains $v$. improving the affordability and consumption of healthier, traditional oils. There are several lessons that can be learned from Myanmar's experience with oil palm expansion that may be applicable to other countries that begin to expand production while supporting sustainable diets, including engaging with smallholder producers, investment in R\&D to ensure that production practices are adapted to local climatic conditions, educating producers about conservation practices before they begin planting and strengthening the governance, transparency and trustworthiness of edible oil supply chains. Lastly, countries investing in edible oil production should consider health properties and ensure that there is synergy between nutrition and health guidance (e.g. food-based dietary guidelines) and production policies.

\section{Acknowledgements}

Acknowledgements: We thank Mark Grindley for providing feedback on the research design. Financial support: This study was funded by an early-career researcher grant from the Nutrition Science Programs (formerly the Sackler Institute for Nutritional Sciences), New York Academy of Sciences. Conflicts of interest: The author has no conflicts of interest. Authorship: S.M.D. conceived the study and carried out data collection with L.K.K., conducted data analysis and wrote the initial manuscript draft. K.N. assisted with data analysis, and J.F. provided feedback on the study design. All authors contributed to the final manuscript. Ethics of human subject participation: This study was conducted according to the guidelines laid down in the Declaration of Helsinki, and all procedures involving research study participants were approved by the Johns Hopkins University Institutional Review Board. Verbal informed consent was obtained from all subjects.

\section{Supplementary material}

For supplementary material accompanying this paper visit https://doi.org/10.1017/S1368980021004353

\section{References}

1. Burlingame BA \& Dernini S (2012) Sustainable Diets and Biodiversity: Directions and Solutions for Policy, Research and Action. Rome: Food and Agriculture Organization of the United Nations.

2. Food \& Agriculture Organization \& World Health Organization (2019) Sustainable Healthy Diets: Guiding Principles. Rome: FAO \& WHO.

3. Lindgren E, Harris F, Dangour AD et al. (2018) Sustainable food systems - a health perspective. Sustain Sci 13, 15051517.

4. Taheripour F, Hertel TW \& Ramankutty N (2019) Marketmediated responses confound policies to limit deforestation from oil palm expansion in Malaysia and Indonesia. PNAS 116, 19193-19199.

5. OECD \& FAO (2019) OECD-FAO Agricultural Outlook 2019-2028. Rome: OECD Publishing/Food and Agriculture Organization of the United Nations; available at https://doi.org/10.1787/agr_outlook-2019-en （accessed March 2020).

6. Mielke T (2017) Global Supply, Demand and Price Outlook for Vegetable Oils as Well as for Palm Oil. http://www.mpoc.org. my/upload/Paper\%201\%20-\%20Global\%20Supply\%20\&\%20 Demand\%20Outlook\%20for\%20Oils\%20\&\%20Fats\%20in\% 202017\%20-\%20Thomas\%20Mielke,\%20Oilworld.compres sed.pdf (accessed March 2018).

7. Byerlee D, Falcon WP \& Naylor R (2017) The Tropical Oil Crop Revolution: Food, Feed, Fuel, and Forests. New York: Oxford University Press.

8. Wan L (2018) Food Firms Set to Be Hit by Rising Palm Oil Prices as South East Asian Production Dips. Foodnavigator. com (accessed July 2018).

9. Pirker J, Mosnier A, Kraxner F et al. (2016) What are the limits to oil palm expansion? Glob Environ Change 40, 73-81.

10. Qaim M, Sibhatu KT, Siregar H et al. (2020) Environmental, economic, and social consequences of the oil palm boom. Annu Rev Resour Econ 12, 321-344.

11. Muñoz I, Schmidt JH \& Dalgaard R (2014) Comparative life cycle assessment of five different vegetable oils. In Proceedings of the 9th International Conference on Life Cycle Assessment in the Agri-Food Sector (LCA Food 2014), San Francisco, California, USA, 8-10 October, 2014, pp. 886-894. American Center for Life Cycle Assessment, 2014.

12. Reddington CL, Yoshioka M, Balasubramanian R et al. (2014) Contribution of vegetation and peat fires to particulate air pollution in Southeast Asia. Environ Res Lett 9, 094006. 
13. Vijay V, Pimm SL, Jenkins CN et al. (2016) The impacts of oil palm on recent deforestation and biodiversity loss. PLoS One 11, e0159668.

14. Rohman A \& Che Man YB (2011) Palm oil analysis in adulterated sesame oil using chromatography and FTIR spectroscopy. Eur J Lipid Sci Tech 113, 522-527.

15. Zambiazi RC, Przybylski R, Zambiazi MW et al. (2007) Fatty acid composition of vegetable oils and fats. B Ceppa Curitiba 25, 111-120.

16. Oguntibeju OO, Esterhuyse AJ \& Truter EJ (2009) Red palm oil: nutritional, physiological and therapeutic roles in improving human wellbeing and quality of life. BrJ Biomed Sci $\mathbf{6 6}$, 216-222.

17. Fattore E, Bosetti C, Brighenti F et al. (2014) Palm oil and blood lipid-related markers of cardiovascular disease: a systematic review and meta-analysis of dietary intervention trials. Am J Clin Nutr 99, 1331-1350.

18. Sun Y, Neelakantan N, Wu Y et al. (2015) Palm oil consumption increases LDL cholesterol compared with vegetable oils low in saturated fat in a meta-analysis of clinical trials-3. J Nutr 145, 1549-1558.

19. World Health Organization (2018) Healthy Diet - Fact Sheet No. 394 2018. Geneva: WHO.

20. Herforth A, Arimond M, Álvarez-Sánchez C et al. (2019) A global review of food-based dietary guidelines. Adv Nutr 10, 590-605.

21. Thaung NH (2011) Integration of Myanmar domestic agricultural marketing into ASEAN. J Manag Policy Pract 12, 96104.

22. FAOSTAT (2021) Food and Agriculture Data. http://www. fao.org/faostat/en/\#home (accessed May 2020).

23. Favre R \& Myint K (2009) An Analysis of the Myanmar Edible Oil Crops Sub-Sector. Rome: Rural Infrastructure and AgroIndustries Division, Food and Agriculture Organization of the United Nations.

24. Connette G, Oswald P, Songer M et al. (2016) Mapping distinct forest types improves overall forest identification based on multi-spectral Landsat imagery for Myanmar's Tanintharyi Region. Remote Sens $\mathbf{8}, 882$.

25. Myers N, Mittermeier RA, Mittermeier CG et al. (2000) Biodiversity hotspots for conservation priorities. Nature 403, 853-858.

26. Gravers M (2007) Exploring Ethnic Diversity in Burma. Copenhagen: NIAS Press.

27. Smith M \& Allsebroko A (1994) Ethnic Groups in Burma. London: Anti-Slavery International; available at https://www. burmalibrary.org/docs3/Ethnic_Groups_in_Burma-ocr.pdf (accessed May 2020).

28. Snitwongse K \& Thompson WS (2005) Ethnic Conflicts in Southeast Asia. Singapore: Institute of Southeast Asian Studies.

29. San Thein U, Diepart JC, Moe H et al. (2018) Large-Scale Land Acquisitions for Agricultural Development in Myanmar: A Review of Past and Current Processes. MRLG Thematic Study Series, 9. Vientiane: MRLG.

30. Bhagwat T, Hess A, Horning N et al. (2017) Losing a jewel rapid declines in Myanmar's intact forests from 2002-2014. PLoS One 12, e0176364.

31. Downs SM, Payne A \& Fanzo J (2017) The development and application of a sustainable DIETS framework for policy analysis: a case study of Nepal. Food Policy 70, 40-49.

32. Hawkes C, Fox E, Downs SM et al. (2020) Child-centered food systems: reorienting food systems towards healthy diets for children. Glob Food Secur 27, 100414.

33. Gelli A, Hawkes C, Donovan J et al. (2015) Value Chains and Nutrition: A Framework to Support the Identification, Design, and Evaluation of Interventions. Washington, DC: International Food Policy Research Institute.

34. Downs SM, Glass S, Linn KK et al. (2019) The interface between consumers and their food environment in
Myanmar: an exploratory mixed-methods study. Public Health Nutr 22, 1075-1088.

35. Dubowitz T, Ncube C, Leuschner K et al. (2015) A natural experiment opportunity in TWO low-income urban food desert communities. Health Educ Behav 42, Suppl. 1, 87S-96S.

36. Environmental Investigation Agency (2016) Green Desert: Communities in Tanintharyi Renounce the MSPP Oil Palm Concession. https://eia-international.org/wp-content/uplo ads/Green-Desert-FINAL.pdf (accessed July 2017).

37. Nomura K, Mitchard ET, Patenaude G et al. (2019) Oil palm concessions in southern Myanmar consist mostly of unconverted forest. Sci Rep $\mathbf{9}, 1-9$.

38. Nicholas K, Fanzo J \& MacManus K (2018) Palm oil in Myanmar: a spatiotemporal analysis of the effects of industrial farming on biodiversity loss. Glob Health Sci Pract 6, 210-222.

39. Purnomo H, Okarda B, Demawan A et al. (2020) Reconciling oil palm economic development and environmental conservation in Indonesia: a value chain dynamic approach. Forest Policy Econ 111, 102089.

40. Pacheco P, Gnych S, Dermawan A et al. (2017) The Palm Oil Global Value Chain: Implications for Economic Growth and Social and Environmental Sustainability. Bogor, Indonesia: CIFOR.

41. Cuevas S, Downs S, Ghosh-Jerath S et al. (2019) Analysing the policy space for the promotion of healthy sustainable edible oils in India. Public Health Nutr 22, 3435-3446.

42. Shankar B, Thaiprasert N, Gheewala S et al. (2017) Policies for healthy and sustainable edible oil consumption: a stakeholder analysis for Thailand. Public Health Nutr 20, 1126-1134.

43. Fitzpatrick D (1997) Disputes and pluralism in modern Indonesian land law. Yale J Int Law 22, 171-212.

44. Teoh CH (2010) Key Sustainability Issues in the Palm Oil Sector. A Discussion Paper for Multi-Stakeholders Consultations (Commissioned by the World Bank Group). Washington, DC: The World Bank and the International Finance Corporation.

45. Usman T, Airlangga SP \& Sulastuti S (2018) Analysis of the Constitutional Court Decision Number 35/PUU-X/2012 Related to Giving Management Permissions Village Forest to the Knasaimos in Papua. In Proceeding of International Conference: 3rd SHIELD, pp. 276-284.

46. Government of Indonesia (2013) The Constitutional Court of the Republic of Indonesia. Constitutional Court Decision No. 35/PUU-X/2012 of May 2013. https://www.loc.gov/item/ global-legal-monitor/2013-06-03/indonesia-forest-rights-ofindigenous-peoples-affirmed/ (accessed March 2017).

47. Ismail SR, Maarof SK, Ali SS et al. (2018) Systematic review of palm oil consumption and the risk of cardiovascular disease. PLoS One 13, e0193533.

48. Kadandale S, Marten R \& Smith R (2019) The palm oil industry and non-communicable diseases. Bull World Health Organ 97, 118.

49. Mahrt K, Mather D, Herforth A et al. (2019) Household Dietary Patterns and the Cost of a Nutritious Diet in Myanmar. IFPRI Discussion Paper 1854. Washington, DC: International Food Policy Research Institute (IFPRI); available at https://doi. org/10.2499/p15738coll2.133344 (accessed March 2020).

50. Downs SM, Thow AM, Ghosh-Jerath S et al. (2013) From Denmark to Delhi: the multisectoral challenge of regulating trans fats in India. Public Health Nutr 16, 2273-2280.

51. United Nations Industrial Development Organization (UNIDO) (2019) Independent Terminal Evaluation. Strengthening the National Quality Infrastructure (NQI) for Trade - Myanmar. Vienna: UNIDO; available at https:// www.unido.org/sites/default/files/files/2019-11/120027\%20 TE\%20Strengthening\%20National\%20Quality\%20Infrastrutu re\%20Myanmar.pdf (accessed March 2020).

52. Zagaraan A, Mohammadi-Nasrabadi F, Hosseini $\mathrm{H}$ et al. (2019) Challenges of edible oils from farm to industry: views of stakeholders. Food Nutr Bull 40, 99-110. 